\title{
Penerapan Taksonomi Bloom Revisi untuk Meningkatkan Kemampuan Pemahaman Konsep Matematis
}

\author{
Netriwati ${ }^{1}$ \\ ${ }^{1}$ Universitas Islam Negeri Raden Intan Lampung. Jalan Endro Suratmin, Sukarame, Bandar \\ Lampung 35133, Indonesia. \\ E-mail: netriwati@radenintan.ac.id
}

Received : 13-08-2018; Revised : 19-09-2018; Accepted : 30-09-2018

\begin{abstract}
Abstrak
Kemampuan pemahaman konsep peserta didik itu penting. Namun kemampuan pemahaman konsep peserta didik itu tidak tumbuh dengan begitu saja melaikan adanya suatu tindakan dari seorang pendidik yan serius dalam menyikapi masalah ini. Menyusun tujuan pembelajaran secara umum adalah salah satu langkah yang tepat dilakukan oleh pendidik dalam pembelajaran. Taksonomi Bloom Revisi yang akan peneliti gunakan dalam menyusun tujuan pembelajaran dalam penenlitian ini. sehingga penelitian ini bertujuan untuk mendeskripsikan kemampuan mahasiswa dalam pemahaman konsep melalui taksonomi Bloom Revisi. Jenis penelitian ini mengunakan metode deskriptif kualitatif untuk melihat pemahaman konsep mahasiswa dalam pelaksanaan microteaching sesuai dengan langkah-langkah taksonomi bloom revisi pada Pendidikan mahasiswa Matematika UIN Raden Intan Lampng semester VI. Teknik pengumpulkan data adalah tes pada pelaksanaan microteaching dan wawancara. Berdasarkan hasil penilain yang dilihat pada hasil lembaran observasi pada pelaksanaan pembelajaran pada bahwa langakah-langkah Taksonomi Bloom sudah bisa diterapkan sesuai dengan indikator yang dipilih dan pada umumnya mahasiswa sudah bisa memahami konsep matematika dengan baik. Sehingga dapat disimpulkan penerapan Taksonomi Bloom Revisi dalam pembelajaran dapat meningkatkan kemampuan pemahaman konsep peserta didik
\end{abstract}

Abstrak : Kemampuan pemahaman konsep; Taksonomi Bloom Revisi

\begin{abstract}
The ability to understand students' concepts is important. But the ability to understand the concept of students does not grow without just passing on an action from a serious educator in dealing with this problem. Developing learning objectives in general is one of the right steps taken by educators in learning. Bloom Revision Taxonomy that researchers will use in developing learning objectives in this study. so this study aims to describe students' abilities in understanding concepts through Bloom Revision's taxonomy. This type of research uses a qualitative descriptive method to see students' understanding of concepts in the implementation of microteaching in accordance with taxonomic steps of the revised bloom on the Education of Mathematics students at UIN Raden Intan in the sixth semester. Data collection techniques are tests on the implementation of microteaching and interviews. Based on the results of the assessment seen in the results of the observation sheet on the implementation of the learning that the steps of Bloom's Taxonomy can be applied in accordance with the selected indicators and in general students have been able to understand mathematical concepts well. So it can be concluded that the application of Bloom Revised Taxonomy in learning can improve students' ability to understand concepts
\end{abstract}

Keywords: Understanding the Concept, Bloom Revised Taxonomy 


\section{Desimal, 1 (3), 2018 - 348}

Netriwati

\section{PENDAHULUAN}

Salah satu cara peserta didik mampu memecahkan masalah yang diberikan atau ditemui dalam belajar matematika adalah harus memiliki kemampuan dasar yaitu memahami konsepnya terlebih dahulu (Sariningsih \& Purwasih, 2017). Hal ini dikarenakan berbagai konsep matematika memiliki keterkaitan yang kuat antar satu konsep dengan konsep lainnya. Apabila siswa belum menguasai kemampuan dasar dalam memahami matematika tersebut maka tujuan pembelajaran yang diharapkan tidak mungkin tercapai dan dipastikan bahwa siswa akan mengalami kesulitan dalam merancang penyelesaian dan melaksanakan rancangan penyelesaian masalah. Kemampuan pemahaman konsep dalam pembelajaran matematika itu sangat penting. Karena dengan memahami konsep dalam belajar matematika adalah kunci untuk memahami materi yang dipelajari. Menurut Wahyuni, (2015) konsep merupakan suatu ide abstraksi yang mewakili objek-objek, kejadian-kejadian, kegiatan-kegiatan, atau hubunganhubungan yang mempunyai atributatribut yang sama. Sedangkan Fatqurhohman, (2016) mengemukakan konsep sebagai ide abstrak yang memungkinkan kita mengklasifikasi objek-objek serta mengklasifikasikan apakah objek-objek itu termasuk kedalam ide abstrak tersebut. Pengetahuan konsep yang kuat akan memberikan kemudahan dalam meningkatkan pengetahuan prosedural matematika siswa. Sehingga dengan pemahaman konsep, siswa akan mampu mengaitkan serta memecahkan permasalahan dengan berbekal kemampuan dasar melalui konsep yang sudah dipahaminya. Berdasarkan hal ini maka dapat disimpulkan bahwa kemampuan pemahaman konsep peserta didik sangatlah penting untuk memahami materi pembelajaran dalam rangka hasil belajar yang sesuai dengan tujuan yang hendak dicapai.

Merujuk tujuan yang hendak dicapai pendidik maka tujuan utama pendidik adalah adalah merumuskan tujuan khusus beserta materi pelajarannya. Tujuan khusus yang telah dirancang sebelumnya itu tentu mampu dalam membantu kemampuan pemahaman peserta didik (Rosmaiyadi, Mariyam, \& Juliyanti, 2018). Namun dalam penelitian peneliti terfokus merancang tujuan umum pembelajaran, karena selain dari kemampuan pemahaman konsep yang dimiliki oleh peserta didik, kemampuan-kemmapuan lain juga penting dirancang tujuan dalam tujuan umum. Perancangan tujuan umum yang digunakan oleh peneliti adalah Taksonomi. Menurut Bloom dalam Sofiyah, (2015) Taksonomi dalam bidang pendidikan digunakan untuk klasifikasi tujuan instruksional; ada yang menamakannya tujuan pembelajaran, tujuan penampilan, atau sasaran belajar, yang digolongkan dalam tiga klasifikasi umum atau ranah (domain), yaitu: (1) ranah kognitif, berkaitan dengan tujuan belajar yang berorientasi pada kemampuan berpikir; (2) ranah afektif berhubungan dengan perasaan, emosi, sistem nilai, dan sikap hati); dan (3) ranah psikomotor (berorientasi pada keterampilan motorik atau penggunaan otot kerangka). Namun Taksonomi Bloom telah mengalami revisi yaitu pada ranah kognitif yang merupakan salah satu kerangka dasar untuk pengkategorian tujuan-tujuan pendidikan, penyusunan tes, dan kurikulum di seluruh dunia. Revisi itu berisikan enam kategori pokok dengan urutan mulai dari jenjang yang rendah sampai dengan jenjang yang 
paling tinggi, yakni: pengetahuan (knowledge);

(comprehension);

pemahaman

penerapan

(application); (4) analisis (analysis); (5) sintesis (synthesis); dan (6) evaluasi (evaluation) (Gunawan \& Palupi, 2016).

Melihat pemaparan tersebut maka kerucutnya penelitian ini adalah untuk mencoba menerapkan Taksonomi Bloom yang telah direvisi yaitu merancang terlebih dahulu tujuan pembelajaran secara umum dalam pembelajaran matematika untuk meningkatkan kemampuan pemahaman konsep matematis peserta didik. Karena dalam pemaparan sebelumnya begitu penting kemampuan pemahaman konsep matematis peserta didik. Merujuk taksonomi Bloom Revisi penelitian pernah dilakukan oleh (Gunawan \& Palupi, 2016) namun penelitian ini hanya terfokus dalam kerangka pembelajaran. Penelitian oleh (Amirulloh, Rustaman, \& Sriyati, 2014) namun penlitian ini hanya terfokus untuk soal SNMPTN Biologi. Penelitian oleh Taufiq, (2015) penelitian ini terfokus untuk tes kemampuan kognitif peserta didik. Penelitian yang berbeda dilakukan oleh peneliti yaitu penenliti terfokus menerapkan Taksonomi Bloom Revisi dalam meningkatkan kemampuan pemahaman konsep peserta didik. Ditinjau dari kemampuan pemahaman konsep peserta didik banyak penelitian yang dilakukan oleh penelitian terdahulu yaitu oleh (Agustina, 2016; Farnika, Ikhsan, \& Sofyan, 2015; Herawati, Siroj, \& Basir,
2010; Ningsih, 2016; Ramadhani, 2017) namun penelitian ini tefokus menggunakan media pebelajaran, model ataupun strategi pembelajaran.

\section{METODE}

Jenis penelitian ini adalah penelitian deskriptif kualitatif. Subjek dalam penelitian ini adalah mahasiswa jurusan pendidikan matematika semester VI kelas A yang berjumlah 32 orang dan Kelas B yang berjumlah 32 orang .dengan mata kuliah Microteacing. Data penelitian didapatkan dari hasil observasi atau pengamatan dari peristiwa, perilaku atau aktivitas mahasiswa saat pembelajaran berlangsung dan wawancara. Kemudian data penelitian ini dianalisa menggunakan analisis data kualitatif (Creswell, 2014)

\section{HASIL DAN PEMBAHASAN}

Berdasarkan hasil ujian akhir pelaksanaan microteaching yang diikuti oleh 61 orang yang terdiri dari kelas A pengikut 32 orang dan kelas B sebanyak 32 orang. Pemahaman konsep mahasiswa dalam pelaksanaan microteaching tidaklah sama setiap pertemuan selalu ada saja mahasiswa yang mengalami kesulitan dalam menyampaikan runtutan dari materi yang belum sesuai dengan apa yang mereka rancang. Setelah dilakukan tes dipereoleh data sebagai berikut:

Tabel 1. Rekapitulasi Persentase Ketuntasan Secara Individu

\begin{tabular}{|c|c|c|c|c|c|c|c|c|}
\hline \multirow{2}{*}{$\begin{array}{l}\text { No } \\
1\end{array}$} & \multicolumn{3}{|c|}{$\begin{array}{l}\text { Perolehan Nilai } \\
\text { Kelas A }\end{array}$} & \multirow[t]{2}{*}{ Jumlah } & \multicolumn{3}{|c|}{$\begin{array}{c}\text { Perolehan Nilai } \\
\text { Kelas B }\end{array}$} & \multirow[t]{2}{*}{ Jumlah } \\
\hline & A & $\mathrm{B}+$ & B & & A & $\mathrm{B}+$ & B & \\
\hline 2 & 18 & 10 & 5 & 32 & 11 & 20 & 2 & 32 \\
\hline$\%$ & 55 & 30,3 & 15,2 & & 33,3 & 60,6 & 6,06 & \\
\hline
\end{tabular}


Berdasarkan Tabel 3. Terlihat bahwa persentase tertinggi memperoleh nilai $\mathrm{A}$ adalah diraih oleh kelas A yaitu $55 \%$. Untuk kelas B persentase tertinggi hanya 33,3 \%. Untuk persentase nilai B yang terendah diperoleh oleh kels B yaitu sebesar 6,06 \%.

Berdasarkan analisa data hasil penelitian, Baik dari kelas A maupun kelas B, diketahui bahwa pembelajaran dengan penerapan Taksonomi Bloom mempunyai pengaruh terhadap peningkatan kemampuan pemahaman konsep matematis mahasiswa. Hal ini ditunjukan dengan adanya perubahan yang berarti antara pertemuan hari demi hari yang bisa dilihat pada hasil lembaran observasi yang sudah dinalisis. Adapun beberapa faktor yang menyebabkan siswa dengan pembelajaran memiliki peningkatan kemampuan pemahaman konsep matematis mahasiswa, yaitu adanya kaitan dengan pembelajaran sebelumnya seperti pembelajaran media pembelajaran, yang pelaksanaan telah diarahkan seperti microteaching dimana dalam kondisi tersebut kreatifitas mahasiswa menjadi terbangun dan dalam mendesain media yang sesuai dengan kriteria materi yang sedang dipelajaikan. Untuk penerapan taksonomi bloomnya juga sudah bisa mengaplikasikan sesuai dengan langkah-langkah yang sudah sebelumnya.Walaupun belum semua dapat menampilan dengan sangat memuaskan.

Hasil tes setiap mahasiswa diakhir penampilannya sudah menunjukan bahwa terdapat peningkatan kemampuan pemahaman konsep matematis mahasiswa baik dari kelas A maupun kelas B hal ini dapat juga dilihat dari hasil nilai akhir semsester mahasiswa setelah dikumulasikan sudah sesuai dengan yang diharapkan beberapa faktor diantaranya: Mahasiswa lebih merasa nyaman dengan pembelajaran karena dalam pemilihan model dan pendekatan pembelajaran yang digunakan dalam pelaksanaan microteaching mereka sudah bisa mengkolaborasikan dengan media dan yang sesuai sehingga teman-teman sejawatnya merasa dapat penyegarkan baru dengan adanya hal-hal tersebut dan dipertemuan berikutnya mereka punya inisiati untuk lebih kreatif

Penelitian ini juga memiliki relevansi dengan penelitian sebelumnya, yaitu penelitian yang dilakukan oleh (Afrilianto, 2016)Hasil penelitiannya yaitu siswa yang diberi penerapan dengan hasil penelitiannya yaitu dengan menggunakan model pembelajaran yang dalam proses pembelajaran secara kelompok lebih baik daripada akan lebih baik. Berdasarkan hasil penelitian sebelumnya yang telah dipaparkan di atas, dikatakan bahwa pengelompokan yang dibuat dalam pelaksanaan akan membuat mahasiswa termotivasi untuk ingin tahu akan permasalahan yang terjadi.

Namun selain itu, pada penelitian juga terlihat pemateri atau tem microteaching juga berinisiatif memberikan memberikan insentif (memberikan pujian atau reward) dan terbukti bahwa pemberian reward bagi kelompok yang paling aktif sebagai pendukung pembelajaran dikelas guna dapat meningkatkan hasil belajar maupun kemampuan pemahaman konsep matematisnya.

Berdasarkan penjelasan di atas dapat disimpulkan bahwa terdapat perbedaan peningkatan kemampuan pemahaman konsep matematis mahasiwa dengan diterapkannya Taksonomi Bloom revisi pada mata kuliah microteaching baik dikelas A maupun di kelas B. Peningkatan kemampuan pemahaman konsep matematis tersebut telah dipaparkan sebelumnya. 


\section{SIMPULAN DAN SARAN}

Secara umum dapat disimpulkan bahwa penerapan Taksonomi Bloom revisi pada mata kuliah Microteaching dapat meningkatkan pemahaman konsep mahasiswa. Hal ini menunjukan bahwa mahasiswa telah memahami langkahlangkah Taksonomi Bloom revisi dengan benar dan mampu mengaplikasikan langkah-langkah Taksonomi Bloom revisi tersebut dalam menyelesaikan soal pada pelaksanaan Microteaching.

Berdasarkan kesimpulan melihat adanya pengaruh bahwa penggunaan Taksonomi Bloom Revisi dapat meningkatkan kemampuan pemahaman konsep matematis peserta didik, maka penulis menyarankan bahwa para pendidik dapat menggunakan Taksonomi Bloom Revisi dalam pembelajaran matematika yaitu menyusun tujuan secara umum sehingga pembelajaran lebih terkondisikan dan dapat meningkatkan kemampuan pemahaman konsep matematis peserta didik

\section{DAFTAR PUSTAKA}

Afrilianto, M. (2016). Strategi Formulate Share Listen Create Untuk Mengembangkan Kemampuan Mathematical Problem Posing Siswa SMP. Didaktik, 8(1), 21-28.

Agustina, L. (2016). Upaya meningkatkan kemampuan pemahaman konsep dan pemecahan masalah matematika siswa SMP Negeri 4 Sipirok kelas VII melalui pendekatan matematika realistik (PMR). EKSAKTA: Jurnal Penelitian Dan Pembelajaran MIPA, 1(1).

Amirulloh, D., Rustaman, N., \& Sriyati, S. (2014). Analisis soal SNMPTN biologi berdasarkan domain kognitif taksonomi bloom revisi dan profil capaian siswa SMA kelas XII. Formica Education Online, 1(1).
Creswell, J. W. (2014). A concise introduction to mixed methods research. Sage Publications.

Farnika, N., Ikhsan, M., \& Sofyan, H. (2015). Peningkatan Kemampuan Pemahaman dan Pemecahan Masalah Matematis Siswa Sekolah Menengah Atas dengan Model Pembelajaran Kooperatif Tipe Team Assisted Individualization. Jurnal Elemen, 1(2). https://doi.org/10.29408/jel.v1i2. 146

Fatqurhohman, F. (2016). Pemahaman Konsep Matematika Siswa dalam Menyelesaikan Masalah Bangun Datar. JIPM Uurnal Ilmiah Pendidikan Matematika), 4(2), 127-133.

Gunawan, I., \& Palupi, A. R. (2016). Taksonomi Bloom-revisi ranah kognitif: kerangka landasan untuk pembelajaran, pengajaran, dan penilaian. Premiere Educandum: Jurnal Pendidikan Dasar Dan Pembelajaran, 2(02).

Herawati, O. D. P., Siroj, R. A., \& Basir, M. D. (2010). Pengaruh pembelajaran problem posing terhadap kemampuan pemahaman konsep matematika siswa kelas xi ipa sma negeri 6 palembang. Jurnal Pendidikan Matematika, 4(1), 7080.

Ningsih, Y. L. (2016). Kemampuan pemahaman konsep matematika mahasiswa melalui penerapan lembar aktivitas mahasiswa (LAM) berbasis teori APOS pada materi turunan. EDUMATICAl Jurnal Pendidikan Matematika, 6(01).

Ramadhani, R. (2017). Peningkatan Kemampuan Pemahaman Konsep Dan Kemampuan Pemecahan Masalah Matematika Siswa SMA Melalui Guided Discovery Learning Berbantuan Autograph. Jurnal Penelitian Dan Pembelajaran Matematika, 10(2). 
Rosmaiyadi, R., Mariyam, M., \& Juliyanti, J. (2018). Pemahaman Konsep Matematis Siswa dengan Strategi Pembelajaran Group To Gruop Exchange Berpendekatan Kontekstual. Jurnal Penelitian Dan Pembelajaran Matematika, 11(1).

Sariningsih, R., \& Purwasih, R. (2017). Pembelajaran Problem Based Learning untuk Meningkatkan Kemampuan Pemecahan Masalah Matematis Dan Self Efficacy Mahasiswa Calon Guru. JNPM Uurnal Nasional Pendidikan Matematika), 1(1), 163-177.

Sofiyah, S. (2015). Pengembangan Paket Tes Kemampuan Berpikir Tingkat
Tinggi Matematika Berdasarkan Revisi Taksonomi Bloom Pada Siswa Kelas V SD.

Taufiq, A. U. (2015). Pengembangan Tes Kognitif Berbasis Revisi Taksonomi Bloom pada Materi Sistemreproduksi untuk Siswa SMA. Jurnal Biotek, 3(2), 1-17.

Wahyuni, L. (2015). Pengaruh Pembelajaran Active Learning Tipe Group To Group Exchange (Gge) terhadap Kemampuan Pemahaman Konsep Matematika Siswa Kelas VIII Mtsn Koto Majidin Tahun Pelajaran 2014/2015. Jurnal Penelitian Universitas Jambi: Seri Humaniora, 17(2). 